PUBLISHED BY

COMENIUS UNIVERSITY BRATISLAVA

FACULTY OF LAW

\title{
TORPEDOING V. CARPET BOMBING: MUTUAL TRUST AND THE RULE OF LAW / Adam Máčaj
}

\author{
Mgr. Adam Máčaj \\ PhD. Student \\ Comenius University in Bratislava \\ Faculty of Law \\ Institute of European Law \\ Šafárikovo nám. 6, 81000 Bratislava \\ Slovakia \\ adam.macaj@flaw.uniba.sk \\ ORCID: 0000-0002-3086-8025

\section{The paper was prepared within the activities of Jean Monnet Centre of Excellence "Rule of Law in the European Union" supported by the European Union (grant No 620758 EPP-1-2020-1-SK-EPPJMO-COE). B}

Submitted: 20 November 2021 Accepted: 17 December 2021 Published: 31 December 2021

\begin{abstract}
The aim of this paper is to assess the most recent developments in the arising threats to the rule of law, in particular from the viewpoint of their impact on the judicial cooperation in light of the principle of mutual trust in the European Union. The paper analyses the development of this principle, the position of the Court of Justice of the European Union on the issue, and its views on recent challenges to the rule of law as a fundamental value of the $E U$, along with positions of other judicial bodies. The assessment then seeks to establish the impact the arising threats to rule of law in the EU, including judicial independence, may exert on the future application of the principle of mutual trust amongst judicial authorities of the Member States, and outline the implications arising therefrom.
\end{abstract}

Key words: rule of law, judicial cooperation, mutual trust, European
Union, judicial independence

Suggested citation:

Máčaj, A. (2021). Torpedoing v. Carpet Bombing: Mutual Trust and the Rule of Law. Slovak Yearbook of European Union Law, vol. 1, 922. https://doi.org/10.54869/syeul.2021.1.268

\section{INTRODUCTION}

The status of rule of law protection, and predominantly the crisis it faces across the European Union (hereinafter "EU") nowadays, have become well-entrenched talking points in legal and political, as well as academic discourse. What has been coined as rule of law crisis and is closely associated with broader crisis of European values has been a matter of concern for a considerable period of time, with Hungary and Poland being notoriously subjected to intense scrutiny (Mos, 2020, p. 280; Scheppele, Kochenov, and Grabowska-Moroz, 2021, p. 119). Yet soon, the third time charm could manifest in Slovenia, where government has been accused of attacking press freedom, judiciary, and even work of the EU's European Public Prosecutor's Office since last year (Herszenhorn and von der Burchard, 2021). With the potential for new threats arising in yet another Member State, while the EU is far from finding a satisfactory way of addressing the already existing concerns, not entirely restricted to actions of Hungarian and Polish governments, one can only wonder whether indeed "each Member State shares with all the other Member States, and recognises that they share with it, a set of common values on which the EU is founded, as stated in Article 2 TEU".? 
Inextricably linked to the implications of questioning whether at least the most rudimentary agreement exists about the fundamental characteristics of these prima facie common values is then the question how do these doubts then impact the mutual trust that is entrenched as an underpinning principle in a plethora of EU legal regimes. This includes those concerning free movement and fundamental aspects of economic integration, the operations of EU private international law (Rizcallah, 2021), or matters of cooperation of Member States even in area of freedom, security and justice, criminal procedures, asylum procedures, and treatment of third-country nationals (Willems, 2016, 2019; Xanthopoulou, 2018). The principle of mutual trust is cornerstone of these areas due to the simple fact that in order to make such mechanisms operable, their legitimacy is based on the premise that other Member States comply with the same fundamental standards, as regards protection of human rights (Spieker, 2019, p. 1192). Moreover, the Court of Justice of the European Union (hereinafter "CJEU") established that mutual trust also precludes Member States from second-guessing each other and their policies as regards level of national human rights observance, but also its specific application in individual cases, save for exceptional situations. ${ }^{2}$

The question which this paper aims to explore is therefore whether, in light of the recent developments shaking the very core understandings of rule of law and shared EU values with the strength of the eponymous carpet bombing, can mutual trust be operationalized amongst Member States and their judiciaries not as a ground for cooperation, but a safeguard of these common values. The hypothesis to be verified through assessment of the CJEU jurisprudence and human rights standards in comparison with situation in various Member States is that the presumption of equivalent level of human rights protection can be rebutted when significant deficiencies in rule of law and protection of human rights threaten the values EU declares as shared among the Member States.

\section{STATE OF PLAY - EU INSTITUTIONS, ARTICLE 7 OF THE TREATY ON THE EUROPEAN UNION, AND THE RULE OF LAW}

The full and complex description of all threats and perceived violations of rule of law and EU values would require a considerably more extensive account and detail than is viable and pertinent for this paper, even should the analysis focus on conduct of single or a handful of states that are considered to be the most responsible for violations of art. 2 of the Treaty on the European Union (hereinafter "TEU"). Nevertheless, a concise summary of gravest concerns ban be ascertained not only through academic viewpoint, but also in findings of a multitude of organizations and institutions. These provide a birdseye view on the scope of the issues threatening the ability of Member States to trust each other in providing an equivalent protection to the values they all hold in high regard, at least as far as law in books is concerned.

For one, Poland has been condemned for systemic threat to the rule of law concerning its reform of the Constitutional Tribunal, as regards not only its composition, but effectiveness of its procedure, and implementations of its rulings, ${ }^{3}$ as well as changes to functioning and procedure of general courts, attacks on judicial independence, and

\footnotetext{
${ }^{2}$ Court of Justice of the European Union, opinion 2/13 of 18 December 2014, ECLI:EU:C:2014:2454, para. 192. ${ }^{3}$ European Commission, Commission Recommendation (EU) 2016/1374 of 27 July 2016 regarding the rule of law in Poland (C/2016/5703); Commission Recommendation (EU) 2017/146 of 21 December 2016 regarding the rule of law in Poland complementary to Recommendation (EU) 2016/1374 (C/2016/8950).
} 
reforms forcing appointed judges out of their positions. ${ }^{4}$ These concerns were similarly noted in the opinions of European Commission for Democracy through Law (hereinafter "Venice Commission"), ${ }^{5}$ which also cautioned against the attempts of legislature and government of Poland to strip the judiciary of powers in ruling on issues of constitutional importance and hamper its capacity to safeguard the constitution. ${ }^{6}$ Same points have been raised by the European Commission in support of its proposal to find Poland in clear risk of a serious breach of the rule of law as one of the values shared by the EU and its Member States. ${ }^{7}$

In a similar manner, Hungary has been a matter of concern for the institutions of the EU even before the situation in Poland, when rule of law and democracy, conjoined under the overarching narrative of the EU values as soon as 2011, were in the spotlight in the context of media plurality and freedom of expression in Hungary, ${ }^{8}$ as well as the creation of a new Hungarian constitution. ${ }^{9}$ Like a forebearer of things to come in Poland, the reasons for caution soon expanded into many other values, including protection of human rights, equality, and non-discrimination, in light of attacks on judicial independence, lowering the retirement age of judges, termination of their mandates before statutory envisaged periods, but also shielding legislation from judicial review, or hampering exercise of religious freedom. ${ }^{10}$ The Venice Commission voiced its concerns similarly, firstly in a fairly conciliatory manner, praising attempts to reform the Hungarian constitution, although warning about lack of transparency, ${ }^{11}$ before switching to a substantially more critical narrative later on, similarly citing the abovementioned concerns. ${ }^{12}$ The sheer volume of opinions adopted by the Venice Commission since then concerning Hungary speaks, pun intended, volumes. At the time of writing the paper, twenty country-specific opinions overall concerned Hungary, nineteen of them adopted since the process of writing a new constitution was initiated. On a quantitative basis, the situation in Poland has generated only six opinions from the Venice Commission since 2015, in the course of six years, less than one third of opinions concerning Hungary adopted in the course of ten years. ${ }^{13}$

The response and alarms, once again, were not confined to bodies dealing with rule of law or human rights, but raised wider political implications. Similarly, these culminated in the resolution calling on the Council to find Hungary in clear risk of a serious breach of values of the EU, citing all of the concerns referenced above, as well as privacy

\footnotetext{
${ }^{4}$ Commission Recommendation (EU) 2017/1520 of 26 July 2017 regarding the rule of law in Poland complementary to Recommendations (EU) 2016/1374 and (EU) 2017/146 (C/2017/5320).

${ }^{5}$ European Commission for Democracy through Law, Opinion no. 833/2015 Opinion on amendments to the Act of 25 June 2015 on the Constitutional Tribunal of Poland, 11 March 2016, CDL-AD(2016)001.

${ }^{6}$ European Commission for Democracy through Law, Opinion no. 860/2016 Poland opinion on the act on the Constitutional Tribunal, 14 October 2016, CDL-AD(2016)026.

7 European Commission, Proposal for a Council decision on the determination of a clear risk of a serious breach by the Republic of Poland of the rule of law, 20 December 2017, COM(2017) 835 final.

${ }^{8}$ European Parliament, Resolution on media law in Hungary, 10 March 2011, P7_TA(2011)0094.

${ }^{9}$ European Parliament, Resolution on the Revised Hungarian Constitution, 5 July 2011, P7_TA(2011)0315.

${ }^{10}$ European Parliament, Resolution on the recent political developments in Hungary (2012/2511(RSP)), 16 February 2012, P7_TA(2012)0053.

${ }^{11}$ European Commission for Democracy through Law, Opinion no. 614/2011 on three legal questions arising in the process of drafting the New Constitution of Hungary, 28 March 2011, CDL-AD(2011)001.

12 European Commission for Democracy through Law, Opinion no. 621/2011 on the new Constitution of Hungary, 20 June 2011, CDL-AD(2011)016

${ }^{13}$ European Commission for Democracy through Law, Documents by opinions and studies. Opinions (country specific). List of countries for which there are opinions. Retrieved from: < https://www.venice.coe.int/WebForms/documents/by_opinion.aspx?lang=EN >, last accessed 17 September 2021.
} 
protection, academic freedom and other concepts interlinked with Art. 2 of the TEU. ${ }^{14}$ In the case of Hungary, however, unlike the situation in Poland, the call upon the Council came from the European Parliament (hereinafter "EP"), not the Commission.

What both situations have in common is the stasis the EU institutions found themselves ever since procedure under Art. 7(1) of the TEU had been initiated. Both countries have been subject of multiple hearings in the Council, yet so far, no result has been reached, with European Parliament criticizing the Council not only for lack of any result concerning the hearings, but also informal and irregular structure of the hearings, lack of participation of the EP in the hearings, and even overly narrow scope of the issues which Commission raised against Poland when initiating Art. 7 procedure. ${ }^{15}$ The lack of results has been similarly criticized by civil society as well (Ligue de Droits de l'Homme, 2021), however the latest hearings in June 2021 still do not imply any development in the outcomes, with meetings laconically stating that "substantive scope of the hearing[s] was the reasoned proposal of the European Commission that triggered it" (Council of the European Union, 2021).

\section{WAY FORWARD - TOWARDS A JUDICIAL ENFORCEMENT AND EMPOWERMENT OF MEMBER STATE COURTS?}

With the results of the political process under Art. 7 being manifestly lackluster, it is no wonder that various actors started to utilize their powers in a way that is not reliant on political bodies, but legal process. Apart from substantial role of the infringement proceedings, initiated mostly by the European Commission (cf. Blauberger and Kelemen, 2017; Bogdanowicz and Schmidt, 2018), judicial bodies in Member States are exploring the possibilities of utilizing the EU law to protect shared values within the sphere of their jurisdiction, especially when it is connected to legal orders of states notorious for their flouting of EU values, as outlined above. This judicial approach was not attempted only by the courts in Poland or Hungary, ${ }^{16}$ but even in courts of other Member States, when confronted with protection of human rights or the rule of law outside of their own countries (Canor, 2013; von Bogdandy and Spieker, 2019).

As already outlined above, the national judges facing these cases have to bear in mind however the principle of mutual trust and its limitations on the possibility to question other Member States' conduct. Mutual trust has always played an important role in schemes related to judicial cooperation between the respective Member States, and it was determined by the CJEU that not only courts in one Member State are precluded from examining jurisdiction of courts in another, ${ }^{17}$ but also the principle of mutual trust precludes derogations from the lis pendens rule, even if the court first seized of an action cannot rule on the matter within a reasonable time, which in itself creates a violation of right to a fair trial. ${ }^{18}$ On the other hand, not even mutual trust was strong enough to override the rules on exclusive jurisdiction recognised in EU private

\footnotetext{
${ }^{14}$ European Parliament, Resolution on a proposal calling on the Council to determine, pursuant to Article 7(1) of the Treaty on European Union, the existence of a clear risk of a serious breach by Hungary of the values on which the Union is founded (2017/2131(INL)), 12 September 2018, P8_TA(2018)0340.

${ }^{15}$ European Parliament, European Parliament resolution on ongoing hearings under Article 7(1) of the TEU regarding Poland and Hungary (2020/2513(RSP)), 16 January 2020, P9_TA(2020)0014.

${ }_{16} \mathrm{Cf}$. Court of Justice of the European Union, A. K., CP and DO, joined cases no. C-585/18, C-624/18 and C-625/18, judgment of 19 November 2019, ECLI:EU:C:2019:982.

${ }_{17}$ Court of Justice of the European Union, Overseas Union Insurance, case no. C-351/89, judgment of 27 June 1991, ECLI:EU:C:1991:279, § 25.

${ }^{18}$ Court of Justice of the European Union, Gasser v. Misat, case no. C-116/02, judgment of 9 December 2003, ECLI:EU:C:2003:657, § 72.
} 
international law, and courts can examine whether exclusive jurisdiction is respected by the court first seized of the dispute in another Member State, before resorting to application of the lis pendens rule. ${ }^{19}$

Mutual trust and mutual recognition are also closely interlinked, ${ }^{20}$ to the concept of ordre public and the public policy exception, which exists as a counterweight to the presumption that all Member States in the EU comply with a set of common standards and values (cf. Böse, 2015).

More extensively, ordre public could be construed even as a measure designed to establish a common standard of protection of human rights across all Member States, in order to protect fundamental values and rules adopted at the EU level itself (Corthaut, 2012, p. 257). It would then imply that protection of public policy is nowadays not purely internal affair of each individual Member State (Mezeiová, 2018, p. 73), but rather a responsibility shared between all of them. For example, the principle of nondiscrimination is used as an example of grounds for application of public policy exception, as the measure is often regarded as tool to enforce protection of human rights in crossborder situations (Kiestra, 2014, p. 20). A fortiori, the interplay of mutual trust, human rights, and flouting of common values then manifests in judicial cooperation concerning matters outside the scope of private international law, such as asylum law, or cooperation in criminal matters, where executing states are with increasing frequency arriving at conclusions requiring them to exercise judicial oversight even in matters concerning respect for human rights in the issuing state (cf. Böse, 2015, pp. 144-145).

\section{CASES INVOLVING MUTUAL TRUST AS A MEASURE OF PROTECTING THE RULE OF LAW}

With the Member State courts given power to protect rule of law and values of the EU, even against other Member States where they are all bound by the same set of standards and the principle of mutual trust, comes with an important caveat. The essential question to be answered in order to determine whether mutual trust can be used as a vehicle to enforce EU values is how evident should the disregard for them be in order to allow other Member States to "lose" the trust they have in the legal systems of other Member States. In other words, the viability of this method of value protection must be assessed through the lens of standard of proof in cases coming before the courts. To answer comprehensively when can the presumption that other Member States comply with human rights standards and, by extension, EU values, be rebutted, jurisprudence of European courts provides a substantial interpretive guidance, explored below.

\subsection{Cases involving detention conditions and treatment of persons deprived of their liberty}

European Court of Human Rights (hereinafter "ECtHR"), although not an EU institution or a part of the EU judicial system, dealt with cases concerning mutual trust between EU Member States, in particular in the context of asylum and removal of third country nationals. The seminal judgment of M.S.S. v. Belgium and Greece provided an opportunity for Member States to question the mutual trust when it established that if a "general situation" in Member State is known to the authorities, individuals "should not be

19 Court of Justice of the European Union, Weber, case no. C-438/12, judgment of 3 April 2014, ECLI:EU:C:2014:212, § 60.

${ }^{20}$ Cf. Court of Justice of the European Union, LM, case no. C-216/18 PPU, judgment of 5 July 2018, ECLI:EU:C:2018:586, § 36. 
expected to bear the entire burden of proof"21 to demonstrate their treatment would breach the prohibition of ill-treatment under Art. 3 of the European Convention on Human Rights (hereinafter "ECHR"). Thus, the state authorities, in the view of the ECtHR, cannot merely "assume that the applicant would be treated in conformity with the Convention standards but, on the contrary, to first verify how the Greek authorities applied their legislation on asylum in practice. Had they done this, they would have seen that the risks the applicant faced were real and individual enough". ${ }^{2}$

Such standard of proof seems incomplete, especially considering the fact that it does not specify the standard of proof beyond the "real risk" test established in its previous jurisprudence. ${ }^{23}$ It merely shifts the burden of proof from the prospective applicants to state authorities, requiring them to take active part in assessment of the conditions in the requesting state, once they can ascertain deficiencies in the general situation in other Member States. Without more precise determination of what deficiencies can lead the Member States to refuse cooperation, such a blank check for courts could lead to increase in cases where general considerations of certain countries would allow courts to question, or override, the principle of mutual trust in the EU, and turn it inside out.

More detailed guidance can therefore be found in also in the jurisprudence of the CJEU, which held that removal of asylum seekers to other Member State cannot take place where "they cannot be unaware that systemic deficiencies in the asylum procedure and in the reception conditions of asylum seekers in that Member State amount to substantial grounds for believing that the asylum seeker would face a real risk of being subjected to inhuman or degrading treatment". ${ }^{24}$ This interpretation provides several significant qualifications for application of "real risk" in cases involving EU Member States. Firstly, the i) systemic deficiencies must exist in Member State, ii) the second Member State authorities cannot be unaware of them, and iii) these deficiencies create at least substantial grounds to believe the real risk of ill-treatment would be present in case of removal. These deficiencies were recently considered by the ECtHR once again to rebut the presumption of equivalent protection in treatment of detainees in Romanian prisons, where not even investigations of the executing French authority could satisfy the presumption in light of available information about conditions in Romanian prisons and lack of safeguards and assurances of the requesting state. ${ }^{25}$

Assessing this test from the viewpoint of situation concerning rule of law in Poland and Hungary, it can be well concluded, as many bodies have, that deficiencies have a systematic character, and given the notoriety the two states have across the EU as regards their rule of law status, other Member States would certainly face an uphill battle arguing that their authorities were unaware about the deficiencies. On the other hand, concerning these states, while real risk of ill-treatment may be present in respect of certain individuals, it is not an issue associated with rule of law in those countries.

\footnotetext{
${ }^{21}$ European Court of Human Rights, M.S.S. v. Belgium and Greece, app. no. 30696/09, judgment (GC) of 21 January 2011, ECLI:CE:ECHR:2011:0121JUD003069609, § 352.

22 European Court of Human Rights, M.S.S. v. Belgium and Greece, app. no. 30696/09, judgment (GC) of 21 January 2011, ECLI:CE:ECHR:2011:0121JUD003069609, § 359.

${ }^{23}$ Cf. European Court of Human Rights, Soering v. the United Kingdom, app. no. 14038/88, judgment (Plenary) of 7 July 1989, ECLI:CE:ECHR:1989:0707JUD001403888, § 91.

${ }^{24}$ Court of Justice of the European Union, N.S. and others, joined cases nos. C-411/10 and C-493/10, judgment of 21 December 2011, ECLI:EU:C:2011:865, § 94.

${ }^{25}$ European Court of Human Rights, Bivolaru and Moldovan v. France, app. nos. 40324/16 and 12623/17, judgment of 25 March 2021, ECLI:CE:ECHR:2021:0325JUD004032416, §§ 122-126.
} 


\subsection{Cases of rule of law and judicial independence in relation to mutual trust}

Considerations of rule of law rather relate to Art. 6 of the ECHR, and question posed accordingly should be under what circumstances the Member States can consider deficiencies in rule of law so grave that they can refuse cooperation under the principle of mutual trust. In the context of extradition in criminal proceedings, the Othman case was the first actual judgment of the ECtHR in which it found extradition in fact would result in a flagrant denial of justice, having regard to the fact that upon extradition, the applicant would be tried with the use of evidence obtained by torture. ${ }^{26}$ Having regard to the extreme rarity of cases where extradition would result in flagrant denial of justice in violation of the ECHR, it is evident that such test is a strict one and "goes beyond mere irregularities or lack of safeguards in the trial procedures such as might result in a breach of [fair trial]". ${ }^{27}$

Such test remains applicable even in cases where the judicial bodies of two states are participating in a cooperation under the EU law, as although the EU law obliges Member States to presume equivalence in protection of fundamental rights, and EU law leaves no discretion to the Member States, the courts can nevertheless rebut this version of Bosphorus presumption, even in cases of flagrant denial of justice and extradition, on concrete facts of individual cases. Apart from "real risk" of flagrant denial of justice, the applicants must, however, present a serious and substantiated complaint and establish that EU law does not allow them to remedy the situation. ${ }^{28}$

In light of the fact that rebuttal of the Bosphorus presumption is permissible under the ECHR only in cases where EU law itself does not allow such remedy, the content of CJEU jurisprudence must therefore be assessed. Similarly to the ECtHR, the cases deal both with issues of ill-treatment, as well as violations of right to a fair trial. In the former group, it has been recalled that mutual recognition and mutual trust are essential in operation of the area of freedom, security and justice, and has been held that only exceptionally, the circumstances warrant a derogation from those principles. ${ }^{29}$ After reiterating the standard of real risk of ill-treatment, the CJEU also outlined useful list of evidence to be used in the determination, including judgments of international courts and other documents of international organizations like the Council of Europe, or the United Nations. Nevertheless, when assessing the standard of proof in demonstrating the real risk, the CJEU held that general information about e. g. detention conditions in the Member State of the issuing authority cannot in and of itself suffice to refuse extradition, and individual circumstances of the person concerned must be assessed, ${ }^{30}$ a consideration not assessed by the CJEU in cases dealing with treatment and systematic deficiencies of asylum systems (von Bogdandy et al., 2021, pp. 398-399). ${ }^{31}$

\footnotetext{
${ }^{26}$ European Court of Human Rights, Othman (Abu Qatada) v. the United Kingdom, app. no. 8139/09, judgment of 17 January 2012, ECLI:CE:ECHR:2012:0117JUD000813909, §§ 282-285.

${ }_{27}$ European Court of Human Rights, Othman (Abu Qatada) v. the United Kingdom, app. no. 8139/09, judgment of 17 January 2012, ECLI:CE:ECHR:2012:0117JUD000813909, § 260.

${ }^{28}$ European Court of Human Rights, Pirozzi v. Belgium, app. no. 21055/11, judgment of 17 April 2018, §§ 6264.

${ }^{29}$ Court of Justice of the European Union, opinion 2/13 of 18 December 2014, ECLI:EU:C:2014:2454, para. 191-192; Court of Justice of the European Union, Aranyosi and Căldăraru, joined cases nos. C-404/15 and C659/15 PPU, judgment of 5 April 2016, ECLI:EU:C:2016:198, § 82.

${ }^{30}$ Court of Justice of the European Union, Aranyosi and Căldăraru, joined cases nos. C-404/15 and C-659/15 PPU, judgment of 5 April 2016, ECLI:EU:C:2016:198, §̧ 88-94.

${ }^{31}$ Cf. Court of Justice of the European Union, N.S. and others, joined cases nos. C-411/10 and C-493/10, judgment of 21 December 2011, ECLI:EU:C:2011:865.
} 
Interestingly, in cases concerning rule of law specifically, the CJEU established that mutual trust and its implementation through the judicial cooperation and the European Arrest Warrant (hereinafter "EAW") is contingent upon independence of the issuing authorities, as right to a fair trial and not only ECHR and Charter, but also Art. 19 of the TEU requires such independence of Member State authorities. The real risk of being tried by a tribunal that is not independent therefore may pose obstacle from acting upon an issued $\mathrm{EAW}^{32}$ which is a situation not per se recognized by the ECHR in is cases concerning possible flagrant denial of justice. Nevertheless, even such cases require specific individual assessment to establish, whether the particular person concerned would be in real risk of trial before court that is not independent or impartial. The generalized concerns about judicial systems in other Member States are not therefore sufficient grounds for national courts to override the mutual trust. ${ }^{33}$ Not even concerns about independence of particular courts with jurisdiction in specific proceedings can bring about such override in absence of the individual assessment part of the test (Biernat and Filipek, 2021, pp. 413-414).

With the individual assessment firmly standing and binding national courts, another attempt to challenge the mutual trust in respect of countries flouting the rule of law came by questioning the judicial nature of courts issuing the EAWs due to the attacks on their independence. The approach was partly justified and initiated by the cases in which the CJEU refused to grant the status of judicial authority to Ministry of Justice in Lithuania and prosecution offices in Germany due to its susceptibility to receiving instructions on particular EAW cases from the executive. ${ }^{34}$ Nevertheless, in cases where the issuing authorities were in fact classified as courts, the CJEU refused the option of not recognizing courts as judicial authorities issuing the EAW. In the case of prosecution offices in Germany, it did so "on account of statutory rules and institutional framework", while "systemic or generalised deficiencies" in judicial independence do not warrant such approach, as it would refuse the position of judicial authority to all courts of a Member State, without taking into consideration their actual conduct in each case. ${ }^{35}$ Having regard to the plethora of forms and numbers of measures of curtails strangling the judicial independence in Poland (von Bogdandy et al., 2021, p. 392), it is conceivable that some of them might be construed as statutory rules and institutional framework that could deprive individual courts in Poland of their status as an issuing judicial body by courts in other Member States, yet such possibilities have not been explored by the CJEU in the $L$ and $\mathrm{P}$ judgment. The requirement of individual assessment of conditions relating to fair trial and judicial independence was upheld yet another time.

\section{CONCLUSION}

The principle of mutual trust in the EU Member States is staunchly defended as a background against which a plethora of cooperative efforts of the Member States take place. Nevertheless, it has been, at least potentially, conceded that it can serve as a vehicle for national courts to check situation in other Member States as regards

\footnotetext{
32 Court of Justice of the European Union, LM, case no. C-216/18 PPU, judgment of 5 July 2018, ECLI:EU:C:2018:586, §§ 58-60.

${ }^{33}$ Court of Justice of the European Union, LM, case no. C-216/18 PPU, judgment of 5 July 2018, ECLI:EU:C:2018:586, § 68.

34 Court of Justice of the European Union, Kovalkovas, case no. C-477/16 PPU, judgment of 10 November 2016, ECLI:EU:C:2016:861; Court of Justice of the European Union, OG and PI, joined cases nos. C-508/18 and C-82/19 PPU, judgment of 27 May 2019, ECLI:EU:C:2019:456.

${ }^{35}$ Court of Justice of the European Union, L and P, joined cases nos. C-354/20 PPU and C-412/20 PPU, judgment of 17 December 2020, § 48.
} 
protection of EU values and the rule of law, before resorting to trusting the judicial system of the issuing Member States. To put such control in practice, however, far more is required of the executing courts than finding a real risk of human rights violations, as required by the ECtHR in cases of extradition into third countries. Refusal to execute an EAW, or, mutatis mutandis, even other measure of judicial cooperation built upon the principle of mutual trust, on grounds associated to rule of law or judicial independence, faces a stringent test developed in the LM judgment, one that is not easily satisfied in all its three steps (Biernat and Filipek, 2021, p. 419).

Concerning the general deficiencies in rule of law or judicial systems in Hungary and Poland, there is ample evidence to consider these deficiencies proven in most cases that could appear before courts in the EU (see part 2). Even concerning the specific judicial bodies, evidence casting doubt on their institutional independence has been recognized by the CJEU, and it even asked urged the national courts to disapply the conflicting provisions under the primacy of EU law. ${ }^{36}$ Nevertheless, in the area of mutual trust and judicial cooperation, the proof of individual being specifically affected by the changes to the judicial system broadly undermining the rule of law, is still a stringent test that is most likely to remain unfulfilled in a variety of cases. With further developments in both the attacks on rule of law, and in the institutional response, as well as resulting judicial proceedings in international and national courts, the upcoming application of the test in practice is likely to change as well, warranting further research.

At the same time, the CJEU also leaves the proverbial ball in the European Council's hands, when it outlined the possibility that it could potentially suspend operation of the EAW as a consequence of procedure under Art. 7(2) of the TEU, and execution of all subsequent EAWs would then automatically have to be refused by national courts in respect of the impacted Member State. The CJEU provided de facto guidelines on what potential sanctions could be adopted, should the remaining institution ever find consensus on the matter. In the absence of one, the individual assessment of real risk remains the rule. ${ }^{37}$

A second avenue for questioning the strength and viability of mutual trust opened via questioning whether the politicized courts are to be regarded as judicial authorities capable of issuing requests for mutual cooperation, in the light of such status being denied to prosecution offices liable to take instructions from the executive. While the CJEU seems to have brushed off such argument for now, the eponymous torpedo could be launched from Strasbourg, with the ECtHR already declaring that the independence and impartiality of a court goes hand in hand with the question of a "tribunal established by law", and grave deficiencies in the principles of judicial independence and impartiality must be a part of the assessment in cases questioning whether the court, whose independence is challenged, is in fact established by law. ${ }^{38}$ Through such assessment, it found already that applicants were deprived of right for a trial before tribunal established by law in various situations. The similar conclusions were made, on the face of specific facts, as regards Constitutional Court, Disciplinary Chamber of the Supreme Court, as well as Chamber of Extraordinary Review and Public Affairs of the Supreme Court, three separate bodies of judiciary in Poland that were reformed or created since the start of

\footnotetext{
${ }^{36}$ Cf. Court of Justice of the European Union, A.B. and others, case no. C-824/18, judgment of 2 March 2021, ECLI:EU:C:2021:153.

37 Court of Justice of the European Union, LM, case no. C-216/18 PPU, judgment of 5 July 2018, ECLI:EU:C:2018:586, §§̧72-73

${ }^{38}$ European Court of Human Rights, Xero Flor w Polsce sp. z o. o., app. no. 4907/18, judgment of 7 May 2021, ECLI:CE:ECHR:2021:0507JUD000490718, § 247.
} 
assault on Polish courts. ${ }^{39}$ With such determinations becoming apparently the new trend of disputing the judicial reforms assaulting rule of law, the question to be answered in future litigations and potentially preliminary rulings is, whether absence of tribunal established lawfully is an indication of deficient "statutory rules and institutional framework" that made the bodies concerned subjected to the executive. ${ }^{40}$ If a court were to make such a finding, it could then deny the affected courts standing under the instruments of mutual cooperation, a nuclear option to be made in order to urge Member States to conform to EU values. Whether any national court would resort to launching such a torpedo, and whether CJEU would consider such approach compliant with the EU law under the most recent developments of its own jurisprudence and judgments of the ECtHR, remains to be seen.

In sum, it is evident that mutual trust, as proposed by the hypothesis above, is not a principle to be followed blindly, and it comes with its own set of obligations to be maintained if judicial cooperation is to remain functional. However, the presumption concerning mutual trust remains a strong one, and even though most actors have by now asserted the potential to overrule it, divergencies in approach to individual cases can be identified, which makes the possibility to rebut the mutual trust subject to strict caveats. Both the CJEU and the ECtHR recognize presumption of equivalent protection as a particularly strong one, albeit rebuttable. In recent times, the ECtHR in fact found several instances of such presumptions being rebutted. On the other hand, the CJEU, having jurisdiction over preliminary rulings, steers Member State courts towards stringent approach that impacts the possibilities of national judges making a finding as impactful as the most recent judgments of the ECtHR, finding several courts in Poland to be unlawfully established. In light of such limitations through preliminary rulings, it remains to be seen whether mutual trust finds its day in court in Member States, or will still be subject of frequent preliminary rulings and applications to the ECtHR. The answer to the question this paper sought to explore is therefore that mutual trust can eventually find itself with Art. 7 of the TEU, or Art. 258 of the TFEU, among a group of instruments that could be operationalized to protect the EU values. However, this particular tool has been historically regarded as strongly supporting cooperation among Member States, not a torpedo to be launched against one another. Such strong historical roots prevent the full potential of mutual trust in protecting the EU values to fully flourish yet. More importantly, even if the current rule of law crisis results in a paradigm change and mutual trust will be eventually utilized in enforcement of the EU values, it remains to be seen whether it can sink the battlecruiser of what has been dubbed the illiberal democracy, or barely make a dent in its hull.

\section{BIBLIOGRAPHY:}

Biernat, S., and Filipek, P. (2021). The Assessment of Judicial Independence Following the CJEU Ruling in C-216/18 LM. In: A. von Bogdandy, P. Bogdanowicz, I. Canor, C. Grabenwarter, M. Taborowski, and M. Schmidt (Eds.), Defending Checks and

\footnotetext{
${ }^{39}$ European Court of Human Rights, Xero Flor w Polsce sp. z o. O., app. no. 4907/18, judgment of 7 May 2021, ECLI:CE:ECHR:2021:0507JUD000490718, § 290; European Court of Human Rights, Reczkowicz v. Poland, app. no. 43447/19, judgment of 22 July 2021, ECLI:CE:ECHR:2021:0722JUD004344719, § 281; European Court of Human Rights, Dolińska-Ficek and Ozimek v. Poland, app. nos. 49868/19 and 57511/19, judgment of 8 November 2021, ECLI:CE:ECHR:2021:1108JUD004986819, § 354.

${ }^{40} \mathrm{Cf}$. Court of Justice of the European Union, L and P, joined cases nos. C-354/20 PPU and C-412/20 PPU, judgment of 17 December 2020, § 48.
} 
Balances in EU Member States (pp. 403-430). Berlin, Heidelberg: Springer Berlin Heidelberg. Retrieved from https://doi.org/10.1007/978-3-662-62317-6_16

Blauberger, M., and Kelemen, R. D. (2017). Can courts rescue national democracy? Judicial safeguards against democratic backsliding in the EU. Journal of European Public Policy, 24(3), pp. 321-336. Retrieved from https://doi.org/10.1080/13501763.2016.1229357

Bogdanowicz, P., and Schmidt, M. (2018). The infringement procedure in the rule of law crisis: How to make effective use of Article 258 TFEU. Common Market Law Review, 55(4), pp. 1061-1100.

Böse, M. (2015). Human Rights Violations and Mutual Trust: Recent Case Law on the European Arrest Warrant. In Human Rights in European Criminal Law (pp. 135145). Cham: Springer International Publishing. Retrieved from https://doi.org/10.1007/978-3-319-12042-3_8

Canor, I. (2013). My brother's keeper? Horizontal solange: "An ever closer distrust among the peoples of Europe." Common Market Law Review, 50(2), pp. 383-421.

Corthaut, T. (2012). EU ordre public. Leiden: Kluwer Law International.

Council of the European Union. (2021). General Affairs Council, 22 June 2021.

Herszenhorn, D., and von der Burchard, H. (2021, July). Rule of law disputes cast shadow over opening of Slovenia's EU Council presidency. Politico.

Kiestra, L. R. (2014). The Impact of the European Convention on Human Rights on Private International Law. The Hague: T.M.C. Asser Press. Retrieved from https://doi.org/10.1007/978-94-6265-032-9

Ligue de Droits de l'Homme. (2021). Request to the Portuguese Presidency to take action on the deteriorating situation in Poland.

Mezeiová, L. (2018). Inštitút výhrady verejného poriadku v medzinárodnom práve súkromnom. In Constitutional Framework for Entering into International Treaties. Bratislava Legal Forum 2018. (pp. 70-76). Bratislava: Comenius University in Bratislava, Faculty of Law.

Mos, M. (2020). Ambiguity and interpretive politics in the crisis of European values: evidence from Hungary. East European Politics, 36(2), pp. 267-287. Retrieved from https://doi.org/10.1080/21599165.2020.1724965

Rizcallah, C. (2021). The Principle of Mutual Trust in EU law in the Face of a Crisis of Values.

Scheppele, K. L., Kochenov, D. V., and Grabowska-Moroz, B. (2021). EU Values Are Law, after All: Enforcing EU Values through Systemic Infringement Actions by the European Commission and the Member States of the European Union. Yearbook of European Law, 39(1), pp. 3-121. Retrieved from https://doi.org/10.1093/yel/yeaa012

Spieker, L. D. (2019). Breathing Life into the Union's Common Values: On the Judicial Application of Article 2 TEU in the EU Value Crisis. German Law Journal, 20(8), pp. 1182-1213. Retrieved from https://doi.org/10.1017/glj.2019.84

von Bogdandy, A., Bogdanowicz, P., Canor, I., Rugge, G., Schmidt, M., and Taborowski, M. (2021). A Potential Constitutional Moment for the European Rule of Law: The Importance of Red Lines. In A. von Bogdandy, P. Bogdanowicz, I. Canor, C. Grabenwarter, M. Taborowski, and M. Schmidt (Eds.), Defending Checks and Balances in EU Member States (pp. 385-401). Berlin, Heidelberg: Springer Berlin Heidelberg. Retrieved from https://doi.org/10.1007/978-3-662-62317-6_15

von Bogdandy, A., and Spieker, L. D. (2019). Countering the Judicial Silencing of Critics: Article 2 TEU Values, Reverse Solange, and the Responsibilities of National 
Judges. European Constitutional Law Review, 15(3), pp. 391-426. Retrieved from https://doi.org/10.1017/S1574019619000324

Willems, A. (2016). Mutual Trust as a Term of Art in EU Criminal Law: Revealing its Hybrid Character. European Journal of Legal Studies, 9(1), pp. 210-249.

Willems, A. (2019). The Court of Justice of the European Union's Mutual Trust Journey in EU Criminal Law: From a Presumption to (Room for) Rebuttal. German Law Journal, 20(4), pp. 468-495. Retrieved from https://doi.org/10.1017/glj.2019.32

Xanthopoulou, E. (2018). Mutual trust and rights in EU criminal and asylum law: Three phases of evolution and the uncharted territory beyond blind trust. Common Market Law Review, 55(2), pp. 489-509.

Court of Justice of the European Union, Overseas Union Insurance, case no. C-351/89, judgment of 27 June 1991, ECLI:EU:C:1991:279.

Court of Justice of the European Union, Gasser v. Misat, case no. C-116/02, judgment of 9 December 2003, ECLI:EU:C:2003:657.

Court of Justice of the European Union, N.S. and others, joined cases nos. C-411/10 and C-493/10, judgment of 21 December 2011, ECLI:EU:C:2011:865.

Court of Justice of the European Union, Weber, case no. C-438/12, judgment of 3 April 2014, ECLI:EU:C:2014:212.

Court of Justice of the European Union, Aranyosi and Căldăraru, joined cases nos. C404/15 and C-659/15 PPU, judgment of 5 April 2016, ECLI:EU:C:2016:198.

Court of Justice of the European Union, Kovalkovas, case no. C-477/16 PPU, judgment of 10 November 2016, ECLI:EU:C:2016:861.

Court of Justice of the European Union, LM, case no. C-216/18 PPU, judgment of 5 July 2018, ECLI:EU:C:2018:586.

Court of Justice of the European Union, OG and PI, joined cases nos. C-508/18 and C-82/19 PPU, judgment of 27 May 2019, ECLI:EU:C:2019:456.

Court of Justice of the European Union. A. K., CP and DO, joined cases nos. C-585/18, C-624/18 and C-625/18, judgment of 19 November 2019, ECLI:EU:C:2019:982.

Court of Justice of the European Union, L and P, joined cases nos. C-354/20 PPU and C-412/20 PPU, judgment of 17 December 2020.

Court of Justice of the European Union, A.B. and others, case no. C-824/18, judgment of 2 March 2021, ECLI:EU:C:2021:153.

Court of Justice of the European Union, opinion 2/13 of 18 December 2014, ECLI:EU:C:2014:2454.

European Court of Human Rights, Soering v. the United Kingdom, app. no. 14038/88, judgment (Plenary) of 7 July 1989, ECLI:CE:ECHR:1989:0707JUD001403888.

European Court of Human Rights, M.S.S. v. Belgium and Greece, app. no. 30696/09, judgment (GC) of 21 January 2011, ECLI:CE:ECHR:2011:0121JUD003069609.

European Court of Human Rights, Othman (Abu Qatada) v. the United Kingdom, app. no. 8139/09, judgment of 17 January 2012, ECLI:CE:ECHR:2012:0117JUD000813909.

European Court of Human Rights, Pirozzi v. Belgium, app. no. 21055/11, judgment of 17 April 2018, ECLI:CE:ECHR:2018:0417JUD002105511.

European Court of Human Rights, Bivolaru and Moldovan v. France, app. nos. 40324/16 and 12623/17, judgment of 25 March 2021, ECLI:CE:ECHR:2021:0325JUD004032416.

European Court of Human Rights, Xero Flor w Polsce sp. z o. o., app. no. 4907/18, judgment of 7 May 2021, ECLI:CE:ECHR:2021:0507JUD000490718.

European Court of Human Rights, Reczkowicz v. Poland, app. no. 43447/19, judgment of 22 July 2021, ECLI:CE:ECHR:2021:0722JUD004344719. 
European Court of Human Rights, Dolińska-Ficek and Ozimek v. Poland, app. nos. 49868/19 and 57511/19, judgment of 8 November 2021, ECLI:CE:ECHR:2021:1108JUD004986819.

European Commission, Commission Recommendation (EU) 2016/1374 of 27 July 2016 regarding the rule of law in Poland (C/2016/5703).

European Commission, Commission Recommendation (EU) 2017/146 of 21 December 2016 regarding the rule of law in Poland complementary to Recommendation (EU) 2016/1374 (C/2016/8950).

European Commission, Proposal for a Council decision on the determination of a clear risk of a serious breach by the Republic of Poland of the rule of law, 20 December 2017, $\operatorname{COM}(2017) 835$ final.

European Commission, Commission Recommendation (EU) 2017/1520 of 26 July 2017 regarding the rule of law in Poland complementary to Recommendations (EU) 2016/1374 And (EU) 2017/146 (C/2017/5320).

European Commission for Democracy through Law, Opinion no. 833/2015 Opinion on amendments to the Act of 25 June 2015 on the Constitutional Tribunal of Poland, 11 March 2016, CDL-AD(2016)001.

European Commission for Democracy through Law, Opinion no. 860/2016 Poland opinion on the act on the Constitutional Tribunal, 14 October 2016, CDLAD(2016)026.

European Commission for Democracy through Law, Documents by opinions and studies. Opinions (country specific). List of countries for which there are opinions. Retrieved from:

<https://www.venice.coe.int/WebForms/documents/by_opinion.aspx?lang=EN>.

European Parliament, Resolution on media law in Hungary, 10 March 2011, P7_TA(2011)0094.

European Parliament, Resolution on the Revised Hungarian Constitution, 5 July 2011, P7_TA(2011)0315.

European Parliament, Resolution on the recent political developments in Hungary (2012/2511(RSP)), 16 February 2012, P7_TA(2012)0053.

European Parliament, Resolution on a proposal calling on the Council to determine, pursuant to Article 7(1) of the Treaty on European Union, the existence of a clear risk of a serious breach by Hungary of the values on which the Union is founded (2017/2131(INL)), 12 September 2018, P8_TA(2018)0340.

European Parliament, European Parliament resolution on ongoing hearings under Article 7(1) of the TEU regarding Poland and Hungary (2020/2513(RSP)), 16 January 2020, P9_TA(2020)0014. 
